Roman Budzinowski ${ }^{1}$

\title{
Profesor Andrzej Stelmachowski jako agrarysta
}

1. Mówiąc o Profesorze Stelmachowskim jako agraryście, trzeba już na wstępie zastrzec, że Profesor z sukcesem uprawiał kilka dziedzin prawa. Dlatego ograniczenie rozważań tylko do nauki prawa rolnego nie oddaje bogactwa Jego dorobku naukowego, ale jest zabiegiem usprawiedliwionym $\mathrm{z}$ racji przeznaczenia publikacji, adresowanej właśnie do osób zajmujących się wyłącznie, czy przede wszystkim, agrarystyką.

Niniejsze rozważania są tylko pewną próbą, już z założenia niepełną, charakterystyki formacji naukowej Profesora Stelmachowskiego jako agrarysty. Obejmują one jedynie określenie roli, jaką Profesor odegrał w zakresie wyodrębniania się i rozwoju nauki prawa rolnego, cech warsztatu naukowego i postawy badawczej oraz przesłania płynącego z Jego dokonań.

2. Prawo rolne było najpierw jedną z kilku, a z upływem lat stało się główną dziedziną działalności naukowej Profesora. Jakie były początki fascynacji prawem rolnym, od kiedy można już mówić o Profesorze jako o agraryście? U progu kariery naukowej nic przecież nie zapowiadało, że przyszły naukowiec zajmie się tą, dopiero co wyodrębniającą się, dziedziną prawa. Wszakże pierwsze publikacje dotyczyły prawa pracy i prawa cywilnego (kilku jego działów). Natomiast pierwsze artykuły z problematyki prawnorolnej pojawiły się nieco później, bo dopiero w połowie lat pięćdziesiątych. Profesor podjął bardzo konkretne kwestie: ustalił rolę, charakter prawny i elementy umowy kontraktacji, rozstrzygając przy tej okazji wiele problemów występujących w praktyce ${ }^{2}$, a także udzielił pozytywnej odpowiedzi na pytanie, czy art. $285 \mathrm{kz}$. ma zastosowanie do zobowiązań z umów POM (państwowych ośrodków maszynowych) ze spółdzielniami produkcyjnymi³. Problematyka umowy kontraktacji stała się z resztą przedmiotem odrębnej pracy o charakterze monograficznym ${ }^{4}$, która wywarła istotny wpływ przyszłą regulację tej umowy w kodek-

Uniwersytet Adama Mickiewicza w Poznaniu.

A. Stelmachowski, Zagadnienia prawne kontraktacji, „Państwo i Prawo” 1954, nr 7-8.

A. Stelmachowski, Czy art. 285 kz. ma zastosowanie do zobowiązań z umów POM ze spółdzielniami produkcyjnymi?, „Nowe Prawo” 1956, nr 3.

4 A. Stelmachowski, Kontraktacja produktów rolnych, Warszawa 1960. 
sie cywilnym. Książka ta łączy rozważania typowo cywilistyczne z rozbudowanym wątkiem prawnorolnym, dającym wyraz bardzo dobrej znajomości realiów polskiej wsi.

Kształtowanie się naukowej formacji Profesora jako agrarysty wiążę nie tyle z tymi pracami, co z pochodzącymi z początku lat sześćdziesiątych opracowaniami napisanymi w języku francuskim, a zawierającymi bardziej ogólne przemyślenia na temat funkcji prawa rolnego, roli administracji państwowej czy planowania w rolnictwie ${ }^{5}$. Do tego okresu odnosi się sformułowana przez J. Paliwodę ocena, według której rozwój nauki prawa rolnego był opóźniony w stosunku do rozwoju ustawodawstwa ${ }^{6}$. Opóźnienie widoczne było nie tylko w zakresie „naukowego opracowania" poszczególnych instytucji prawnych, ale zwłaszcza w zakresie refleksji teoretycznej dotyczącej podstaw prawa rolnego.

Teoretyczne refleksje Profesora Stelmachowskiego pojawiły się w okresie przełomowym, gdy została zaniechana forsowana kolektywizacja (chociaż widmo uspołecznienia „krążyło” jeszcze do początku lat osiemdziesiątych) oraz formalnie zakończył się okres przebudowy ustroju rolnego (realizacji reformy rolnej i osadnictwa). W nowych warunkach sformułowane wcześniej koncepcje wyodrębnienia prawa rolnego, określenia jego przedmiotu czy definicje wymagały zweryfikowania. Okazją do w miarę całościowego ujęcia stał się skrypt oraz podręczniki z prawa rolnego z końca lat sześćdziesiątych, w których Profesor był autorem rozważań dotyczących m.in. zagadnień ogólnych ${ }^{7}$.

Dzisiaj można szerzej rozwinąć i skomentować wiele zawartych tam myśli. Jakże trafne jest pierwsze zdanie otwierające rozważania w powołanych wyżej opracowaniach: „Prawo rolne nie może poszczycić się tak długą tradycją jak prawo cywilne." Słusznie Profesor nie wiąże genezy prawa rolnego z samym tylko występowaniem regulacji rolnictwa (niektórych jego aspektów). Historia rozwoju tych regulacji nie jest bowiem równoznaczna z genezą prawa rolnego we współczesnym rozumieniu, jako dającej się wyodrębnić dziedziny ustawodawstwa. Prawo to narodziło się na pewnym etapie rozwoju kapitalizmu, gdy ewidentne stały się różnice miedzy rolnictwem a przemysłem i handlem, gdy rolnictwo - ze względu na swoje cechy swoiste - wymagało specjalnej (czasem szczególnej) regulacji, a prawo cy-

A. Stelmachowski, La fonction du droit rural en Pologne, Rapports polonaise presents au VI-me Congres International de droit Comparée, Societe de legislation Comparée, Varsovie 1962; A. Stelmachowski, L'administration d'Etat dans l'agriculture, "Revue Internationale des Sciences Administraties" 1964, nr 1; A. Stelmachowski, Les reflects juridiques de la planification en agriculture en Pologne, "Atti della Seconda Assemblea" 1964, vol. 3. J. Paliwoda, Polskie prawo rolne, „Acta luridica Agraria” 1999, vol. 1, s. 30. szawa 1967 i 1970. Swoja koncepcję wyodrębnienia prawa rolnego i określenia jego miejsca w systemie prawa profesor Stelmachowski poddał pod dyskusję na konferencji w Sadkach w 1968 r., na której wygłosił wprowadzający referat pt. „Prawo rolne w systemie polskiego prawa” (opublikowany w pracy zbiorowej „Zagadnienia prawne rolnictwa", red. J. Paliwoda, Wrocław-Warszawa-Kraków 1970, s. 5 i n.). 
wilne - ze względu na indywidualizm kodeksów cywilnych z XIX w. - nie było w stanie sprostać wymogom rozwoju rolnictwa w nowych warunkach ${ }^{8}$.

Oryginalne cechy miało też zwrócenie uwagi na czynniki wpływające na swoistość regulacji prawnorolnej, a także wyróżnienie trzech płaszczyzn wyodrębnienia prawa rolnego. Ta swoistość związana jest, zdaniem Profesora, nie tylko z właściwościami rolnictwa jako dziedziny gospodarki narodowej, ale również z wieloma innymi czynnikami (np. politycznymi, psychologicznymi, demograficznymi itp.), które uzasadniają interwencję Państwa. Takie rozumowanie przypomina opracowane bliżej przez A. Carrozzę rozróżnienie dwóch czynników rozwoju prawa rolnego: czynnika technicznego i czynnika politycznego ${ }^{9}$. Również rozpatrywanie wyodrębnienia prawa rolnego na trzech płaszczyznach (legislacyjnej, dydaktycznej i naukowej) odpowiada tokowi argumentacji występującemu w literaturze włoskiej.

Rozważając wyodrębnienie prawa rolnego w płaszczyźnie naukowej, Profesor zauważył, że „nauka prawa rolnego jest u nas w stadium kształtowania się; stąd wiele zagadnień jest jeszcze niedostatecznie wyjaśnionych i spornych", a dziesięć lat później, w podręczniku napisanym wspólnie z B. Zdziennickim stwierdził, że ,prawo rolne jako nauka już się wyodrębniło, nie wyszło jednak całkowicie ze stadium kształtowania się"10. To zastrzeżenie jest zrozumiałe, zważywszy na szybkie zmiany legislacji prawnorolnej oraz związaną z nimi konieczność weryfikacji koncepcji doktrynalnych.

Impulsu do rozwoju tej nauki dostarczył sam Profesor Stelmachowski, który definiując prawo rolne, pominął aspekt tzw. socjalistycznej przebudowy rolnictwa, dzięki temu pozbawił je cechy tymczasowości. Oznaczało to odejście od definiowania prawa rolnego jako prawa przebudowy ustroju rolnego (w kierunku socjalistycznym). Według zaproponowanej definicji prawo rolne to „całokształt norm prawnych regulujących stosunki społeczne związane z kształtowaniem przez Państwo ustroju rolnego i produkcji rolnej z punktu widzenia interesu społeczno-gospodarczego"11. To ujecie definicyjne prawa rolnego nie było stałe, Profesor zmieniał je odpowiednio do rozwoju ustawodawstwa.

Odwołanie się do interesu społeczno-gospodarczego w pierwotnej definicji (pominięte już w definicji z 1980 r.) pełniło rolę weryfikatora, przesądzało o uznaniu jakiejś instytucji za instytucję prawa rolnego. Dla przykładu, według Profesora, sprzedaż sąsiedzka produktów rolnych, chociażby nawet między rolnikami, stanowi wyłączną domenę prawa cywilnego, gdyż nie jest tu zaangażowany interes społeczno-gospodarczy. Kontraktację produktów rolnych natomiast włącza się do prawa lacyjnych i koncepcji doktrynalnych, Poznań 2008, s. 106 i n.

9 Rozwinięte w pracy: R. Budzinowski, Problemy ogólne.., s. 26 i n. oraz 42 i n.

10 A. Stelmachowski, B. Zdziennicki, Prawo rolne, Warszawa 1980, s. 9.

11 A. Stelmachowski, J. Selwa, Prawo rolne.., s. 13. 
rolnego jako specyficzną formę skupu, objętą planem skupu, mogącą spełniać inne ważne funkcje przy przebudowie ustroju rolnego ${ }^{12}$.

Jeszcze później Profesor zrezygnował z określenia w definicji prawa rolnego roli Państwa w kształtowaniu ustroju rolnego i produkcji rolnej. Wystąpiło ono, co prawda, w podręczniku opublikowanym po $1989 \mathrm{r} .{ }^{13}$, ale nie przystawało już do funkcjonowania rolnictwa w ramach gospodarki rynkowej, w której działalność rolniczą prowadzą autonomiczne podmioty. W ostatecznym ujęciu definicyjnym prawo rolne zostało określone jako ,całokształt norm prawnych regulujących stosunki społeczne związane z kształtowaniem ustroju rolnego, w tym także produkcji rolnej i rynku rolnego"14. Ujęcie to miało na tyle charakter ogólny, że mogło być odniesione i łatwo dostosowane również do obecnej legislacji rolnej.

Istotnym wątkiem występującym w związku $\mathrm{z}$ wyodrębnieniem prawa rolnego była charakterystyka metod regulacji prawnej określonych stosunków społecznych w rolnictwie. Już w skrypcie z 1966 r. znalazło się fundamentalne stwierdzenie, że „prawo rolne nie ma jakiejś własnej, sobie tylko właściwej metody, na wzór prawa cywilnego, administracyjnego, czy karnego. Operuje wszystkimi trzema, z tym, że w zależności od potrzeb i bieżącej polityki Państwa nasilenie przymusu bywa mniejsze lub większe, a w konsekwencji ta lub inna metoda wysuwa się na plan pierwszy" ${ }^{15}$. Rozważania o metodach były pogłębiane w kolejnych wydaniach podręczników z prawa rolnego, z bardzo trafnym zwróceniem uwagi na punkt widzenia producenta rolnego. Dla tego producenta bowiem ważniejsze jest, jak pisał Profesor, czy Państwo stosuje metody nakazowo-zakazowe czy bodźcowe.

Dzisiaj, już w nowych warunkach i na innym etapie rozwoju prawa rolnego, można stwierdzić, że koncepcje Profesora Stelmachowskiego odegrały zasadniczą rolę w rozwoju nauki prawa rolnego, legły u podstaw procesu wyodrębniania się tej gałęzi w ramach systemu prawa. Miały one również ogromne znaczenie inspirujące, o czym świadczy dyskusja zapoczątkowana wspomnianym już referatem na temat miejsca prawa rolnego w systemie prawa wygłoszonym na konferencji w 1968 r. ${ }^{16}$ Gdyby owego wkładu intelektualnego oraz inspiracji nie było, to rozbudowywane od końca lat pięćdziesiątych ustawodawstwo rolne pozostawałoby zapewne przez długi czas raczej działem legislacji, a nauka prawa rolnego znajdowałaby się nadal w stadium kształtowania się.

\footnotetext{
12 Ibidem, s. 14.

13 P. Czechowski, M. Korzycka-Iwanow, S. Prutis, A. Stelmachowskii, Polskie prawo rolne na tle ustawodawstwa Unii Europejskiej, Warszawa 1993, s. 9.

14 P. Czechowski, M. Korzycka-Iwanow, S. Prutis, A. Stelmachowski, Polskie prawo rolne na tle ustawodawstwa Unii Europejskiej, Warszawa 1999, s. 19.

15 A. Stelmachowski, T. Kuta, J. Selwa, Prawo rolne, s. 12. Zdanie to Profesor powtórzył również w kolejnych wydaniach podręczników z prawa rolnego. go w systemie prawa, „Państwo i Prawo” 1973, nr 1 oraz J. Paliwoda, Problem usytuowania prawa rolnego w systemie polskiego prawa oraz kodyfikacji prawa rolnego, „Nowe Prawo” 1973, nr 1.
} 
2. Gdy chodzi o cechy warsztatu naukowego oraz postawy badawczej Profesora Stelmachowskiego, warto zwrócić uwagę na kilka aspektów.

W pierwszej kolejności wypada przypomnieć, że Profesor swoją fascynacje prawem rolnym rozpoczął w czasie, gdy był już cywilistą o liczącym się i uznanym dorobku. To wyjście od cywilistyki pozwoliło inaczej spojrzeć na regulację rolnictwa. Jako osoba, która cechy stosunku cywilnoprawnego upatrywała w autonomiczności stron, musiał Profesor dostrzegać złożoną i zróżnicowaną pozycję podmiotów w stosunkach społecznych regulowanych przez prawo rolne. Znalazło to wyraz we wspomnianych rozważaniach na temat metod regulacji prawnej, a także w dostrzeganiu słabej pozycji producenta rolnego. Na tym tle oczywiste są więc Jego postulaty co do wzmocnienia pozycji tego producenta w umowie kontraktacji ${ }^{17}$, czy polepszenia tzw. spokojnej starości rolnikom indywidualnym ${ }^{18}$. Nie dziwi również udział Profesora w podpisaniu Porozumień Rzeszowsko-Ustrzyckich w 1981 r., w wyniku których nastąpiło uchylenie podstaw przymusowego przejmowania ziemi chłopskiej na własność Państwa oraz zniesienie uprzywilejowania tzw. sektora uspołecznionego $\mathrm{w}$ rolnictwie.

Cechą charakterystyczną postawy badawczej Profesora było funkcjonalne podejście do prawa, także prawa rolnego. Sam Profesor nie poprzestawał jedynie na rozważaniach dogmatycznych, pokazywał związki między różnymi zjawiskami czy zdarzeniami oraz działanie prawa w praktyce. To ułatwiało oddzielenie tego, co było jedynie fasadowe czy deklarowane, od tego, co było rzeczywiste. Samo wydanie aktu prawnego nie stanowiło jeszcze sukcesu, ważne były skutku jego stosowania. Funkcjonalne podejście do prawa znajdowało wyraz w prowadzonych (wraz ze współpracownikami) badaniach empirycznych. Ich efektem było wiele publikacji książkowych z bardzo ciekawymi stwierdzeniami. Dla przykładu, zaskakiwać mogło spostrzeżenie, że w okresie wprowadzania ograniczeń podziału gospodarstw rolnych widoczny był, wprawdzie powolny, proces ich koncentracji występujący w trudnych warunkach ,zamrożenia” rozwoju gospodarstw chłopskich ${ }^{19}$.

Profesor nie ulegał pokusie przypodobania się władzy, o co w nauce prawa rolnego - ze względu na związki tego prawa z polityką - było i jest nadal bardzo łatwo; nie podsuwał oczekiwanych przez władzę rozstrzygnięć. Dla przykładu, na wspomnianej konferencji w 1968 r. zabrał głos na tle referatu dotyczącego zadań nauki prawa rolnego w świetle uchwał V zjazdu PZPR, ale zwracał uwagę na konieczność podniesienia produkcyjności rolnictwa, a więc zniesienia antybodźców, które by stały temu na przeszkodzie. Nowością było też opowiedzenie się za zwiększeniem pomocy dla regionów rolniczo upośledzonych. Z kolei na konferencji w Popowie

17 A. Stelmachowski, Kontraktacja...

18 A. Stelmachowski, Problemy ludzi starych na wsi w aspekcie prawnym, „Nowe Prawo” 1972, nr 7-8.

19 Przemiany własności ziemi w rolnictwie polskim, red. A. Stelmachowski, Wrocław 1974. 
w 1980 r. zauważył, że podstawowym problemem prawa rolnego nie była jego kodyfikacja, lecz zapewnienie skuteczności norm. Tu zestawienie założeń polityki rolnej z regulacją prawną uzasadniało krytykę m.in. prawnej regulacji obrotu nieruchomościami rolnymi ${ }^{20}$. Z kolei gdy w latach dziewięćdziesiątych krytykowany był zbyt wysoki udział państwa w finansowaniu społecznych ubezpieczeń rolniczych, Profesor uważał, że stanowi on formę wspierania rolnictwa, a takie wsparcie jest potrzebne.

Wypada też podkreślić, że Profesor wprowadził naukę polskiego prawa rolnego na europejskie salony. Znany jest Jego udział w pracach Europejskiego Komitetu Prawa Rolnego, a także podniesienie rangi Polskiego Stowarzyszenia Prawa Rolnego. Profesor wziął udział w licznych konferencjach naukowych, a także opublikował wiele prac w czasopismach zagranicznych. Był pierwszym polskim agrarystą, który podjął współpracę z nauką włoską, posiadającą - jak wiadomo - najdłuższą tradycję, gdy chodzi o rozważania teoretyczne. Te związki z nauką obcą stawały się też inspiracją do wzbogacenia rozważań o polskim prawie. Jakże często, dla przykładu, sięgało się w naszej literaturze do rozróżnienia etapów rozwoju prawa rolnego, u którego podstaw znajdowały się przemyślenia na tle udziału w konferencji we Włoszech ${ }^{21}$.

3. O wielkości uczonego świadczą nie tylko dokonania naukowe, czy postawa badawcza, ale też przesłania, które wypływają z jego dorobku, z wyznawanych wartości, dla kolejnych pokoleń agrarystów. Warto zwrócić uwagę na pięć - zdaniem autora - najważniejszych przesłań.

Pierwsze przesłanie, zdawałoby się oczywiste, wcale nie jest łatwe. Należy kontynuować dzieło Profesora i rozwijać naukę prawa rolnego, mając na uwadze nowe uwarunkowania, w tym też rolę wspólnej polityki rolnej. Profesor, mimo swego ogromnego zaangażowania w politykę w okresie ostatnich dwudziestu lat, zdawał sobie sprawę ze zmian dotyczących samego rolnictwa, jego otoczenia, uwarunkowań międzynarodowych, z konieczności dostosowywania regulacji prawnych oraz poszukiwania nowych ujęć teoretycznych. To właśnie wymienione czynniki wymuszają weryfikację dotychczasowych koncepcji doktrynalnych leżących u podstaw wyodrębnienia prawa rolnego. Zdaniem Profesora, powinni zająć się tym młodzi badacze. Agraryście nie powinien być też obcy udział w pracach legislacyjnych, ale też w popularyzacji prawa.

20 A. Stelmachowski, Skuteczność norm jako podstawowy problem legislacyjny prawa rolnego, (w:) Rola prawa w rozwoju gospodarki rolnej kraju. Materiały z konferencji. Popowo, 15-16 maja 1980 r., Warszawa 1983.

21 M. Błażejczyk, A. Stelmachowski, Nowe zjawiska w produkcji rolniczej i pararolniczej a ustrój prawny polskiego rolnictwa, „Państwo i Prawo” 1989, z. 1. Zob. np. S. Prutis, Adekwatność instrumentów prawnych do potrzeb rozwoju polskiego rolnictwa. Księga dedykowana Profesorowi Andrzejowi Stelmachowskiemu, Białystok 1991. 
Drugie przesłanie dotyczy przedmiotu badań. Powinien on wychodzić poza samo rolnictwo, obejmować - mówiąc współczesnym językiem - także inne elementy łańcucha żywnościowego. Już w 1980 r. Profesor pisał o ewolucji od rolnictwa do kompleksu żywnościowego (gospodarki żywnościowej) ${ }^{22}$, co miało wyznaczać również kierunek rozwoju regulacji prawnej. Dzisiaj traktuje się rolnictwo jako element agrobiznesu; rola tego działu gospodarki niestety maleje, co wpływa na obniżenie poziomu dochodów rolniczych. Kwestia miejsca rolnictwa w łańcuchu żywnościowym wymaga badań, na co zwraca się uwagę także na poziomie unijnym.

Trzecie przesłanie wyraża zachętę do prowadzenia badań prawnoporównawczych. Profesor był pionierem takich badań w nauce prawa rolnego. Niegdyś A. Lichorowicz szeroko uzasadniał możliwość i konieczność prowadzenia badań prawnoporównawczych w odniesieniu do poszczególnych instytucji prawa rolnego ${ }^{23}$. Zapatrywanie Profesora, by takimi badaniami obejmować nie tylko poszczególne instytucje prawne, ale całe gałęzie prawa ${ }^{24}$, dzisiaj może być już realizowane bez ograniczeń. Prawo rolne stało się, dzięki członkostwu Polski w Unii Europejskiej, prawem w dużym zakresie wspólnym dla państw członkowskich; w regulacji spraw rolnictwa prawo to stanowi część dominującą. Badanie prawa krajowego, w aspekcie prawnoporównawczym, służy doskonaleniu prawa wewnętrznego także z punktu widzenia wdrażania prawa unijnego. Porównanie naszego prawa rolnego z obcymi porządkami prawnymi (zwłaszcza z prawem francuskim i włoskim) wypada niestety niekorzystnie dla prawa polskiego; jego rozwój widoczny jest w zasadzie w tych dziedzinach, które objęte są wspólną polityką rolną.

Czwarte przesłanie przywołuje tak charakterystyczne dla Profesora nawoływanie do funkcjonalnego ujmowania i badania prawa; nawoływanie do tego, by badając prawo rolne, mieć na uwadze zależności między różnymi zjawiskami czy zdarzeniami, by nie poprzestawać jedynie na dogmatyce. Należy badać różne aspekty stanowienia i stosowania prawa, dostrzegać społeczne skutki regulacji prawnych, ale też pewne wartości, które prawo winno wyrażać. Nawet jeśli badania dotyczą zjawisk z zakresu gospodarki, trzeba dostrzegać potrzeby człowieka.

Wreszcie piąte przesłanie wyraża stosunek do młodych badaczy - kontynuatorów i następców. Postawa Profesora świadczyła o bardzo życzliwym stosunku do młodej kadry naukowej, kolejnego pokolenia agrarystów. Profesor dawał jej wyraz przy różnych okazjach. Nie nękał oponentów w dyskusji, a raczej pozytywnie zaskakiwał, wydobywając z wypowiedzi elementy pozytywne, czasem ku zaskoczeniu samego dyskutanta; delikatnie naprowadzał, mówiąc, że „tu właśnie rodzi się

22 A. Stelmachowski, B. Zdziennicki, Prawo rolne.., s. 18.

23 A. Lichorowicz, Dzierżawa gruntów rolnych w ustawodawstwie krajów zachodnioeuropejskich, Warszawa-Kraków 1986.

24 Wyrażone w recenzji pracy A. Lichorowicza, Dzierżawa gruntów rolnych w ustawodawstwie krajów zachodnioeu- 
pole do dyskusji”25. Niech ta postawa będzie drogowskazem wyznaczającym relacje między pokoleniami i zwiastunem rozwoju nauki prawa rolnego w przyszłości.

4. Na koniec wypada dodać wątek osobisty. Nie będąc uczniem Profesora, doświadczałem Jego życzliwości przy różnych okazjach; był moim recenzentem w przewodzie doktorskim oraz w postępowaniu o nadanie tytułu profesorskiego. Nie będąc uczniem Profesora, pozostawałem - czego nie ukrywam - pod Jego wpływem, przechodząc drogę od dogmatyki do teorii prawa rolnego. Nieco ponad pięć lat temu mój macierzysty Uniwersytet - Uniwersytet im. Adama Mickiewicza w Poznaniu - uhonorował swojego wybitnego Doktora uroczystością odnowienia doktoratu. Miałem zaszczyt wystąpić w roli laudatora. Wyrazem uznania zasług Profesora dla rozwoju nauki prawa rolnego była dedykowana Jego pamięci IV polsko-włoska konferencja naukowa zorganizowana przez ośrodek poznański ${ }^{26}$.

W podsumowaniu warto nawiązać do fragmentu laudacji wygłoszonej przez ze mnie na uroczystości odnowienia doktoratu w 2006 r., zmieniając - co oczywiste gramatyczną formę wypowiedzi.

Dokonania Profesora Andrzeja Stelmachowskiego na niwie uniwersyteckiej, niezmiernie bogata i oryginalna twórczość naukowa, zasługują na ogromne uznanie i budzą należny szacunek. Nie sposób zwłaszcza przecenić wkładu Profesora w rozwój prawa rolnego. Bez tego wkładu ta dziedzina wiedzy, ustawodawstwa i dydaktyki nie byłaby tym, czym jest obecnie. Jednakże te dokonania, nawet wsparte działalnością publiczną, nie odzwierciedlają w pełni cech osobowości Profesora Stelmachowskiego. To jest tylko jeden aspekt życiorysu, mierzony nie tylko upływem czasu, ale wysiłkiem intelektualnym, zdeterminowanym wartościami decydującymi o wyborze drogi życiowej, o sposobie życia. Powiedziałbym tak, nawiązując do znanej maksymy „To wielka rzecz być uczonym, ale jeszcze większa być ludzkim” (W. Rodgers). To „bycie ludzkim” przebijało na kartach twórczości i tak bardzo widoczne było w kontaktach z otoczeniem.

W podsumowaniu Zarysu teorii prawa cywilnego Profesor napisał m.in. że „Prawo cywilne nie może być przyjazne tylko dla silniejszych ekonomicznie, musi chronić godność każdego człowieka”. W rozważaniach o kontraktacji z 1960 r. Profesor opowiedział się za wzmocnieniem słabej pozycji producenta rolnego (,chłopa”), a w artykule dotyczącym sytuacji prawnej ludzi starych na wsi sugerował wprowadzenie odpowiednich rozwiązań służących zabezpieczeniu spokojnej starości rolnikom indywidualnym. Przykłady można by mnożyć. Wskazują one niezbicie, że mieszczonej (w:) Andrzej Stelmachowski. Pragmatyczny romantyk, red. K. Zienkiewicz, Warszawa 2011, s. 358. rzycka-Iwanow z Uniwersytetu Warszawskiego. Zob. Sprawozdanie z tej konferencji: R. Budzinowski, „Przegląd Prawa Rolnego" 2010, nr 2. 
Profesor był nie tylko wielkim Uczonym, ale i humanistą wrażliwym na potrzeby drugiego człowieka, a nauka prawa w wydaniu Profesor była po prostu humanistyką.

Swoją fascynację nauką Profesor, jako doskonały dydaktyk, potrafił przekazać studentom, zainteresować ich zwłaszcza niełatwym przedmiotem, jakim było i jest nadal prawo rolne. Wspaniała osobowość i życzliwość przyciągała do Profesora liczne grono adeptów prawa. To dzięki tej życzliwości i zaangażowaniu Profesor potrafił zainteresować pracą naukową liczne grono swoich uczniów, i to na kilku uniwersytetach. Inspiracja zresztą docierała nie tylko do wychowanków. Było w dużej mierze zasługą Profesora, że i piszący te słowa zainteresował się problematyką teorii prawa rolnego. O życzliwości niech świadczy też fakt, że jako Autor uznanego podręcznika z prawa rolnego Profesor zachęcał Profesora Wiktora Pawlaka, pierwszego, długoletniego Kierownika Katedry Prawa Rolnego w Poznaniu, do napisania podręcznika z tego przedmiotu, wychodząc z założenia, że studenci powinni mieć możliwość wyboru pomocy dydaktycznych, a konkurencja będzie sprzyjać rozwojowi tej dziedziny nauki. To stwierdzenie jest nadal aktualne.

Nie mogę zwieńczyć tego podsumowania słowami wypowiedzianymi na zakończenie laudacji - plurimos annos Panie Profesorze. Mam wszakże świadomość, że Profesor nadal będzie obecny w naszych myślach i dokonaniach. 


\section{Professor Andrzej Stelmachowski as a rural Lawery}

Key words: rural law science, branch of law, scientific development, scientific achievements

The subject of this paper are the main features of scientific development of professor Andrzej Stelmachowski as a rural lawyer. It considers the role that he has played in granting autonomy and developing of rural law science, the characteristics of his scientific work, his attitude as a researcher and the message he has passed through his achievements.

According to the Author, the conceptual findings of professor Stelmachowski have been crucial for rural law science development and have constituted the fundamental basis for autonomy of this branch of law within the legal order. They also have been a great source of inspiration. If not this intellectual contribution and inspiration, the rural regulations that have been growing since the late fifties would have remained just a section of legislation, and the rural law science would still be at its formative stage.

The analysis are concluded with the messages deriving from professor's Stelmachowski accomplishments for the future generations of rural lawyers and the general estimation of his life attitude and scientific achievements. 